\title{
On the Model Setting of an Ecological Accountable Government
}

\author{
Ling $\mathrm{Xu}^{1}$, Xiyang Feng ${ }^{2}$ \\ IGuangzhou University, Guangzhou, China, xuling_1@126.com \\ ${ }^{2}$ Guangzhou University, Guangzhou, China, fengxiyang_1@126.com
}

\begin{abstract}
Today, under the background the ecological civilization construction, many scholars are focusing on the issue of how to keep the balance of the economical, social, political and cultural development and try to make all of them in a sustainable development way. In this paper, we put forward the concept of ecological accountable government. On the analysis of the responsibility system of an ecological accountable government, we try to construct the ecological accountable government in the contract way. Then, we consider that the ecological accountable government's contract system was composed of three contract levels, which including the moral contract, the political contract and the executive contract. All these three levels of contract have different functions and definitions, but their goals are the same, which is to try to make the government fulfill its ecological responsibility. Finally, we talk about the constructional thoughts which including six different dimensions, such as the administrative value's construction, the theory basis of the political ethics and some relevant background system settings, the subject of responsibility, the responsible receptors, the content of responsibility, and the responsible mechanisms.
\end{abstract}

KEYWORDS: ecological accountable government, executive contract, government's ecological responsibility, moral contract, political contract

\section{The connotation and dual attributes of the ecotype responsibility government}

On the research of responsible government, scholars at all times and all over the world have analyzed and probed into the political, legal, economic and other plural paths to different degrees. Under the background of ecological civilization construction, we advocate that the concept of sustainable development should be introduced into the effective construction of responsible government to ensure the responsibility and implementation of government ecological responsibility. As a result, the Ecological accountable government emerged as the times require, and its connotation mainly includes the following four aspects:

Firstly, the Ecological accountable government is guided by the concept of "rational ecological man" administrative value. "rational ecological man" is a new concept of administrative value, which is the absorption and reference of the hypothesis of "rational economic man" in classical economics, and the integration and reference of the basic principles and thinking of ecology. While rationally pursuing the balanced development of politics, economy, culture and society, we must also consider intergenerational equity and justice. The administrative value concept of "rational ecological man" is the soul and core of Ecological accountable government construction.

Secondly, the Ecological accountable government aims at the effective implementation of government ecological responsibility. The position of government ecological responsibility in ecotype responsibility government is the upgrade and transformation of the traditional government responsibility system. It covers all the forms and contents of government responsibility, and advocates to push it to the practical level through the form of government responsibility list. In order to follow up the liquidation and accountability. Government ecological responsibility is not based on the original system of government responsibility in the division, in addition to political responsibility, economic responsibility, social responsibility and cultural responsibility in addition to an additional or 
complementary ecological responsibility. This is only a narrow definition of the ecological responsibility of government. The ecological responsibility of government means that the government must bear the responsibility of balanced development of politics, economy, culture, society and so on. At the same time, it must strive for intergenerational fairness and justice.

Thirdly, the Ecological accountable government advocates to lock and investigate government ecological responsibility through contract path. In fact, ecological responsibility in ecotype responsibility government includes two kinds of ecological moral responsibility (subjective responsibility) and ecological post responsibility (objective responsibility). Among them, government ecological moral responsibility is the spiritual control and foundation of government ecological post responsibility, and government ecological post responsibility is the embodiment and extension of government ecological moral responsibility. Under the guidance of the contractual responsibility government theory, we advocate to realize the responsibility of the government ecological moral responsibility to the government ecological post from the three levels of moral contract, political contract and administrative contract, and then to the civil servant student. As the premise and foundation of the future government's ecological responsibility liquidation.

Fourthly, the Ecological accountable government follows the concept-system-mechanism integrated design idea. The initial link of Ecological accountable government construction lies in the "ecological" core construction of administrative value concept. Finally, through the process design and the implementation of the guarantee mechanism to ensure the effective operation of Ecological accountable government. In this process, it is necessary to emphasize the effective integration of ethical construction and institutional design, to realize the institutionalization of ethics and the development and advancement of institutional ethicalization.

In addition, we also need to emphasize that Ecological accountable government has the dual attributes of "ecology" and "contract": on the one hand, it has the aim and mission of seeking ecological justice; on the other hand, It advocates the effective locking and investigation of government ecological responsibility through contract path. Firstly, ecology is the essential attribute of Ecological accountable government, and it is the soul of Ecological accountable government. Ecological accountable government takes the effective pursuit of ecological justice as its goal and mission, which is mainly reflected in the effective bearing of the government's ecological responsibility in reality. Ecological justice is a kind of value idea, it pursues the harmony between human beings and nature. At the same time, the concept of ecological justice is the rational understanding and value judgment of how to regulate the ecological behavior of the ecological subject, and is the ideological basis and value goal of the ecological justice norm. Ecological justice is not only the reflection of human existence, but also the value pursuit of human subject spirit and the foundation of establishing new social order. As the value and ethical pursuit of Ecological accountable government, ecological justice aims at establishing a harmonious social order between man and nature, man and society, and human beings. It is emphasized that the unfair phenomenon and its correction of the behavior of the weak groups by the strong groups in the distribution of benefits, which means "equality, balance, and unity." Win. Secondly, contract is the way to achieve ecological responsibility government. In order to ensure the effective realization of government ecological responsibility in Ecological accountable government, we must find a practical method or path to transform it from the research of political ethics to the level of reality. The effective construction of contractual responsibility government brings us a lot of ideas and enlightenment. The contractual responsibility government advocates that the government's subjective and objective responsibility should be locked in and investigated through the contract path. Ecological responsibility government imitates the idea of contract responsibility government construction, in essence, it is the docking and 
integration of contract responsibility government and ecological ethics, and advocates moral contract, politics. Contract and administrative contract realize the government's ecological responsibility by layer by layer locking and implementation. The ecotype responsibility government takes the government ecological responsibility effective investigation as the goal and the mission. However, before we set about the effective construction of Ecological accountable government, we must have a clear orientation and understanding of the division of government ecological responsibility and its system.

\section{The construction of new government responsibility system in ecotypic responsibility government}

At present, many scholars in China regard government ecological responsibility as a new element and type added to the list of government responsibilities under the spiritual requirements of ecological civilization construction. Based on this idea, many scholars think that the system of government responsibility mainly includes: political responsibility, administrative responsibility, legal responsibility, moral and ethical responsibility and ecological responsibility. There are some limitations in the division of government responsibility system. Firstly, there are overlapping and overlapping problems in the classification of government responsibility system. For example, in reality, the legal responsibility of the government is sometimes the responsibility of the government, the administrative responsibility of the government and even the moral and ethical responsibility of the government. Second, due to the relative division of responsibility on the content, it leads to the ethical dilemma in the process of administrative execution. For example, in the face of moral responsibility and post responsibility conflict, the moral responsibility should be put first, or the effective implementation of post responsibility should be pursued. Third, the ecological responsibility is limited to environmental justice, and it does not highlight the spirit essence of " equality, balance and win-win " pursued by ecological justice. On the pattern of Development of practice and practice.

Aibao Huang believes that the ecological responsibility of the government should refer to the pursuit and realization of natural ecological balance and stability or the natural harmony between man and nature under the guidance of democracy and the concept of service value, and in the specific arrangement of ecological responsibility system. Based on this definition, the author holds that the government responsibility system in ecotypic responsible government should have "ecological" thinking and vision, and the government should use economy, politics and culture. The multidimensional balanced development of society is the goal and mission. It should not be confined to the position of government environmental protection responsibility in shallow ecological politics, but should go deep. The stage in which the government assumes the responsibility of multi-dimensional balanced development in politics, economy, culture and society. At the same time, it also adds the intergenerational justice and justice of the time dimension. Therefore, the government responsibility which the ecotype responsibility government seeks has the "ecology" thought and the connotation, it has realized the reconstruction and the fusion of the government responsibility system with the ecological vision, the concrete manifestation is as follows: First, it effectively expands the dimension of the traditional definition of government responsibility. It not only emphasizes the responsibility of the Government for achieving balanced development among domestic politics, economy, culture and society, but also advocates the introduction of harmonious coexistence among nations into the responsibility of a Government, to break the boundaries of traditional government responsibilities. Secondly, it effectively expands the time dimension of traditional government responsibility definition. Ecotypic responsibility government introduces intergenerational fairness and justice into the definition of government responsibility. Third, it effectively straightens out the relationship 
between government's subjective and objective responsibility, and solves the ethical dilemma caused by the conflict of subjective and objective responsibility caused by the division of traditional governmental responsibility system. The ecotypic responsibility government advocates that the subjective responsibility (moral responsibility) of the government should be taken as the premise and control, and that the objective responsibility of the government (post responsibility) is the embodiment and implementation of the subjective responsibility (moral responsibility), forming a new type of government responsibility system.

The responsibility system of ecotypic responsibility government is divided according to the rules of subjective responsibility (moral responsibility) and objective responsibility (post responsibility). Cooper (1990) believes that in government management activities, responsibility as a form of government management can be divided into constitutional responsibility, political responsibility, administrative responsibility and moral responsibility. The first three are objective responsibilities (also known as post responsibilities), which are prescribed by law, and the latter are subjective responsibilities (moral responsibilities), which reflect the ethical autonomy of national civil servants. We further form the division of government responsibility system of ecotypic responsibility government: it includes the ecological moral responsibility of government There are three levels: the subjective responsibility and the objective responsibility of the government post and the objective responsibility of the civil servant post. At the same time, the three layers of government ecological responsibility have the following relationship:

First, there is a logical relationship, emphasizing the subjective responsibility of the objective responsibility control and infiltration. The subjective responsibility of the government (moral responsibility of the government) should be the soul and guide of the objective responsibility of the government, and the subjective responsibility of the government plays a dominant role in the objective responsibility of the government. The objective responsibility of the government must be consistent with the moral responsibility of the government, and when there is a conflict of responsibility, it must unconditionally fulfill the objective of the moral responsibility of the government. To a great extent, it solves the ethical conflict between objective responsibility and subjective responsibility in the actual operation of government. Second, as far as possible to the form of legal liability externalized, so that the implementation and accountability. In order to ensure the investigation and implementation of the government's moral responsibility, the idea of the contractual responsibility government's accountability is to concretize the government's subjective responsibility through the way of contract, so as to realize the effective locking of the responsibility. Such as the explicit provisions in the form of law and other provisions, the form of the bottom line of law to ensure the metaphysical level of the moral investigation and implementation. In the construction of ecotypic responsibility government, both subjective and objective responsibilities will be externalized as far as possible through the path of contract, and finally achieved by the way of legal liability investigation. The ecological responsibility system in the responsible government is the deconstruction and upgrading of the traditional government responsibility system, rather than an additional responsibility content or index.

\section{Triple contract: realizing the solid locking of 'Government moral responsibility-Government Post responsibility'}

Ecotypic responsibility government has ecological value core, at the same time, the government ecological moral responsibility, the government ecological post responsibility and the civil servant ecological post responsibility should be locked in and investigated through the contractual path.

- The upper contract level of ecotypic responsible government: moral contract 
The moral contract is a contract between the members of the society. It regards the sovereignty of the people as the premise and foundation of its existence, and mainly involves the legitimacy of the state. The mission of the moral contract of ecotypic responsibility government is to investigate the ecological moral responsibility of the government, which is embodied in the content definition and responsibility recovery of the inherent ecological moral responsibility of the state (government). The moral contract of ecotype responsibility government is in the high contract level in the whole government contract system, which is the soul and foundation of the ecotype responsibility government. And it is the initial step and initial stage of the later construction of ecotypic responsible government. Kant's moral contract theory, Rawls' just contract theory and ecological justice theory are the important ideological basis and theoretical origin of the ecotypic responsibility government's moral contract layer. Although the purpose of the moral contract is to effectively lock in the ecological moral responsibility of the government, in reality, it will still be externalized as a form of legal responsibility as far as possible, so that the responsibility can be carried out and liquidated. As to how to effectively realize the externalization of moral contract, we can draw inspiration and reference from many countries' moral legislation and civil servants' professional ethics norms.

- The middle contract level of ecotypic government: political contract

The political contract refers to a contract between a parliament (or a citizen) and a government or a head of government, which mainly deals with the legitimacy of a government and emphasizes the implementation and investigation of the objective responsibility of the government. Political contract is the middle level of ecotypic responsibility government. It is the formation and extension of high contract (moral contract) and the premise and foundation of low contract (administrative contract). Nominally, the two parties to a political contract are the people and a certain government, but in practice, it is often the representative organ that represents the public and the head of a specific government to sign the contract. In order to ensure the effective implementation of the political contract, it is very important to set up a special agency within the representative organization to supervise and liquidate the government's performance responsibility. In a political contract, the power transferred from the people's side is the executive power that the government can exercise. Of course, the people can also show their service attitude towards the government and accept the government's rule and administration by signing a contract. The agenda of governance often becomes an important externalization of political contracts. In the case of a government that is the other party to the contract, it must be implemented article by article on the basis of its policy agenda. When a certain government fails to perform truthfully or has a poor performance during its term of office, the representative organ has the right to liquidate the responsibility of that government. And the most serious consequence is the overthrow of the government, that is, the termination of the contract.

- The lower contract layer of ecotypic government: administrative contract

The administrative contract is a contract between an administrative official (or administrative department) and the government, which emphasizes the implementation and accountability of the post responsibility of an administrative official or administrative department, and mainly involves the legitimacy of an administrative official (civil servant). The administrative contract is the low-level contract layer of the government of ecological responsibility, which involves the level of each specific administrative personnel. Compared with the government contract, the administrative contract and the government contract are all under the unified reflection of the moral contract, which extends from the subjective ecological responsibility of the government to the objective responsibility of the government. But the administrative contract is the further extension and refinement on the basis of the political contract. In addition, the parties to the contract and the parties specifically responsible for responsibility supervision and liquidation are different: an administrative contract is a contract 
between a government official and a government, and its internal oversight body is responsible for the liquidation; while the political contract is the contract between the people and a certain government, which is mainly investigated by the representative organization.

In a word, the contract system of ecotypic responsibility government is a big contract system constructed from three levels, such as moral contract, political contract and administrative contract. Each of the three levels has its function and orientation. The moral contract is the high contract layer, which is responsible for the definition and investigation of the moral responsibility of the government, and is the premise and foundation of the subsequent construction of the contract layer. The political contract is the middle contract layer, which is responsible for the investigation and liquidation of the responsibility of the government post, and is the extension and realization of the responsibility of the government's ecological moral responsibility in a certain government post. The administrative contract is the low contract layer, which aims to investigate and implement the post responsibility of civil servants, and is the embodiment and manifestation of the ecological responsibility of the government at the level of civil servants. For the relationship between these three levels of contract, we can liken it to an ecological tree. The moral contract is similar to the tree root of ecotypic responsible government, which is the soul and foundation of life. The political contract is the trunk, which receives nutrients from the roots and forms the outline and torso of the entire ecological tree. The administrative contract is the branch and leaf of the ecological tree, and it is the most obvious level of the ecological tree. If this big tree of ecotypic responsible government is to grow luxuriantly, it must start with the moral contract at the grass-roots level and lay a good foundation. Then, the transition and upgrade from the government's ecological moral responsibility to the government's post responsibility can be realized through the construction of the framework of the political contract. Finally, through the further deep description of the administrative contract, the final lock of the government ecological responsibility in the specific civil servant post responsibility level is realized, so as to make the realization of ecological responsibility from subjective responsibility to objective responsibility.

\section{Six dimensional construction: Realize the two-way integration of 'institutionalization of ecological ethics- ethicalization of ecological system'}

Under the guidance of the administrative value concept of "rational ecological man", the construction of ecotypic responsibility government advocates following the integrated design idea of "ideal-systemoperational mechanism", so as to realize the two-way integration of the institutionalization of ecological ethics and the ethicalization of ecological system.

There have been a lot of achievements in the exploration of the concept of ecological responsibility in academic circles, but the research on the docking of the transformation of reality is relatively lacking. No matter how good the theory is, if there is no practical system guarantee and supporting design, its practical guiding value and function will be greatly reduced, which will affect the vitality and significance of the theory. Therefore, we call for the institutionalization of ethics, which is not only the externalization of theory, but also an important link of theory in reality. At the same time, there are a lot of institutional studies on the responsibility of government in academic circles. However, in the operation and implementation of the real system, there are often problems of short-lived or virtual operation of the system. One of the most important reasons for this is that the ethical process of the system is inadequate. A successful system design must be guided by conceptual construction. And the spirit and soul behind the system is the premise and key of system design. The lack of corresponding theoretical paving or political and ethical background design will only lead to the shell of the system or mechanization design, which will affect the vitality of the system. Therefore, 
in the construction of ecotypic responsibility government, we must pay attention to the two-way integration of system ethics and ethical institutionalization. From the six dimensions of administrative value concept, background system design and political ethics foundation, responsibility subject, responsibility receptor, responsibility content, responsibility process and mechanism, the integrated design and arrangement of 'concept, institution and operation mechanism' are carried out.

- Establish the concept of the administrative value of 'rational ecological man'

Administrative value is the soul of ecotypic responsible government. The ecotypic responsible government takes the administrative value concept of "rational ecological man" as the new standard and basis of government policy, and emphasizes that the government should take into account the intergenerational equity and sustainable development from the angle of ecological justice in its decision-making. Under the premise that the original pursuit of economic interests, political interests or social interests become a decision standard, the "equity and justice" of the government has given the "ecological justice" of intergenerational equity and ecological sustainable development in the context of the government's pursuit of equity and justice. The author (Xu 2010) has combed its theoretical basis and historical context system in his book Rational Ecological Man - The Study of the Reconstruction of Chinese Administrative Values from the Perspective of Economics and Ecology. Furthermore, the paper puts forward the four derivative administrative value systems, namely, the objective subsystem, the means subsystem, the balance subsystem and the safeguard subsystem of the rational ecological man's administrative values.

- Background system design and political ethical foundation: ecological politics and sovereignty in the people

The theory of ecological politics and the idea of contract are the basis of political ethics of ecotypic responsible government, and the design of contract path based on the theory of people's sovereignty is the background institutional arrangement of ecotypic responsible government. In the 1970s, a new political ideological trend, green pacifism, was formed in western politics, which is the reflection and development of western "green politics" and "green revolution" in politics. The Silent Spring (Carson 1962), The Limits To Growth (Donella et al. 1972), and A Blueprint for survival (Goldsmith et al. 1972) are the foundations of green politics. Green politics is a kind of "non-political politics", which takes sustainable development economy as its main content.

Besides taking the theory of ecological politics as its important basis, the contract theory is also the theoretical guide for the construction of ecotypic responsible government. Contract thought has played a positive role in the theory and practice of different disciplines such as law, economics, politics, and administration. Ancient Greek scholars have used the idea of contract in the discussion of political science long ago. In spite of the different stages of the development of the contract theory in the political science, the scholars have all the emphasis on the research, the most basic ideas of the social contract theory are the same, that is to emphasize that the people and the state can realize the authorization to the state by signing the contract, so as to solve the social state of the contradiction.

- The three-layer positioning of the responsibility subject

The subject of government responsibility refers to the organ responsible for the consequences of government responsibility. In the ecotypic responsibility government, the main body of responsibility exists in the form of systematization, and its composition has three main levels. For the first level, it is mainly embodied as the main form of responsibility of "big government", that is, the social community (state). According to the legitimacy of the existence of the state in the theory of social contract, the purpose and mission of the existence of the social community (state) lies in the pursuit of fairness and justice, and it shoulders the mission of social justice, which is the moral setting and prerequisite for the existence of the state and the government. The ecotypic responsible government takes the effective achievement of ecological justice as its goal and mission, which is also the important reason why the country 
(government) comes into being. The second level of government responsibility is manifested as a specific government, it can be reflected in a certain leadership or government cabinet in reality, here we understand it as "small government." The policy agenda of each government will be different, which is bound to lead to differences in the responsibilities of the specific posts of the different governments. However, the political contract of the ecotypic responsible government will force the government to perform effectively according to its commitments, otherwise it will face the consequences of liability liquidation. The third level of government responsibility of the main body is every government official (civil servant), which is the most basic responsibility subject form in ecotype responsibility government. The list of specific post responsibilities of each civil servant is specified through the administrative contract, which includes both ecological moral and ecological post responsibilities, thus, it can provide the basis and guidance for the subsequent liquidation of responsibilities.

- Classification of three types of responsibility receptors

The government responsibility receptor is the organ responsible for the accountability of the responsible subject, sometimes it is the delegate of power to be responsible for acting as the recipient of the government's responsibility. There are three main types of responsibility receptors in ecotypic responsible government. First, it is the public (or voters), which is the ultimate responsibility of ecotype responsible government receptor. Second, it is the representative organization (that is, parliament, etc.), which is the conventional government responsibility receptor of ecotypic responsible government. Third, it is the courts, political parties or government internal oversight agencies, etc., which is the third kind of government responsibility receptor of ecotypic responsible government. On the construction of ecological responsibility government, it is also necessary to emphasize the authority and effectiveness of government responsibility system, that is, government responsibility receptor. Although it is theoretically believed that government power is a contract between the government and the people, derived from the people's authorization, the public is naturally the recipient of the government's responsibility. In practice, this kind of government responsibility receptor is often investigated and liquidated through its representative organ (that is, parliament, etc.), the regular government responsibility receptor is responsible for the investigation and liquidation of government responsibility. So, as the normal government responsibility receptor, representative organ must be the main form of responsibility receptor for the daily supervision and liquidation of government responsibility.

- The effective externalization of the content of responsibility

In terms of the effectiveness of accountability, the objective responsibility investigation is the most feasible one. The ecotypic responsibility government requires that the content of the government's ecological responsibility must finally be clearly listed in the form of a list of responsibilities, which can be taken as the premise and basis for the supervision and investigation of responsibility. The ecotypic responsibility government advocates the transformation of the subjective responsibility to the objective responsibility through the way of moral contract. First, the effective externalization of the moral contract can be absorbed and used for reference from the practical experience of other countries in the field of moral legislation and professional ethics of civil servants. Second, the effective externalization of political contracts can be solidified by a clear formulation of the policy agenda, supplemented by commitments such as the inaugural address of the head of government. The government's policy agenda is the effective externalization of the political contract, which lists the specific responsibilities of the administration of the government. Third, regarding the externalization of administrative contracts, the main manifestation is the post contracts signed between civil servants and the government. In the post contract of the civil servant, it is necessary to clearly list the responsibility of the specific post. Of course, it also includes some incentive contracts as recognition and encouragement of outstanding performance.

- The arrangement of responsibility process and system 
The construction of ecotypic responsibility government regards the government's ecological responsibility as its goal, in addition to making concrete responsibility lock through explicit ways such as legalization, we must also set up a series of government responsibility mechanisms and processes to ensure the effective achievement of the government's ecological responsibility. The establishment of government ecological responsibility in ecotypic responsibility government mainly follows the following four main stages. The first is the setting stage of government ecological responsibility. It is the logical starting point for the construction of ecotypic responsibility government. It mainly involves locking the content of the government's ecological moral responsibility in an explicit way of contract (such as constitution, law, etc.) and realizing the listing of the government's ecological responsibility. The second is the implementation stage of the ecological responsibility of the government. It is the governance of the government and its civil servants to fulfill their promises. At this stage, it is mainly embodied in the performance of a government's policy agenda when it comes to power and the effective performance of every civil servant's responsibilities. The third is the supervision stage of the ecological moral responsibility of the government. This stage emphasizes the effectiveness and authority of responsibility receptor supervision. In the public (ultimate responsibility receptor), representative organization (conventional responsibility receptor), judicial organ or ruling party, etc. (the third kind of responsibility receptor), the functions and authority of daily supervision and responsibility clearing of representative organization are the main ones, which is supplemented by the authority and function of liability liquidation of the third type of responsibility receptor. The fourth is the evaluation stage of government ecological responsibility. Based on the list of responsibilities of government posts and each civil servant, it compares and evaluates the actual performance of the government and takes it as the basis for the liquidation of responsibilities.

\section{References}

Carson, Rachel. 1962. Silent Spring. Boston: Houghton Mifflin.

Cooper, Terry L. 1990. The Responsible Administrator: An Approach to Ethics for Administrative Role. San Francisco: Oxford Press.

Donella, H. Meadows et al. 1972. The Limits To Growth: A Report for the Club of Rome's Project on the Predicament of Mankind. New York: Universe Books.

Goldsmith, E. et al. 1972. A Blueprint for Survival. Harmondsworth: Penguin.

$\mathrm{Xu}$, Ling. 2010. Rational Ecological Man - The Study of the Reconstruction of Chinese Administrative Values from the Perspective of Economics and Ecology [M]. Beijing: Beijing Institute of Technology Press. 